\title{
Literature Review: Aktivitas Fisik Dan Pola Makan Terhadap Obesitas Peserta Didik Sekolah Dasar
}

\author{
Cyvensa Rustantia Amenani, Oni Bagus Januarto* \\ Universitas Negeri Malang, Jl. Semarang No. 5 Malang, Jawa Timur, Indonesia \\ *Penulis korespondensi, Surel: oni.bagus.fik@um.ac.id
}

Paper received: 7-2-2022; revised: 25-2-2022; accepted: 29-2-2022

\begin{abstract}
Obesity is a disease that is a big problem in parts of the world, this disease attacks all ages, not only adults but also minors. The writing of this article was carried out because the author's aim was to find out whether there was a relationship between physical activity and diet on obesity in elementary school students. Methods: The author collects articles using the Google Scholar database. The keywords used are physical activity on obesity, diet on obesity, and the effect of physical activity on obesity, diet. Vulnerable years are from 2011 to 2020. The article above uses a correlational research design. Some of the articles reviewed have been indexed by Synta S1-S6 or Scimago Q1-Q4. Results: The author found 23 articles with 20 articles published in national journals and 3 international journals. The results of a review conducted on several articles above show that there is a significant relationship between physical activity, diet, and obesity. Conclusion: After reviewing the article, the author found a relationship between physical activity and diet on obesity in elementary school-aged children. The author also found that there are many other causes that influence childhood obesity including genetic factors, environmental factors, and media.
\end{abstract}

Keywords: physical activity; diet; obesity

\begin{abstract}
Abstrak
Obesitas adalah penyakit yang menjadi masalah besar dibelahan dunia, penyakti ini menyerang kesegala umur bukan orang dewasa saja tetapi juga kepada usia anak dibawah umur. Penulisan artikel ini dilakukan karena tujuan penulis untuk mengetahui apakah terdapat hubungan antara aktivitas fisik dan pola makan terhadap obesitas peserta didik sekolah dasar. Metode: Penulis mengumpulkan artikel menggunakan database Google Scholar. Kata kunci yang digunakan aktivitas fisik terhadap obesitas, pola makan terhadap obesitas, dan effect physical activity on obesity, diet. Rentan tahun yaitu mulai dari tahun 2011 hingga tahun 2020. Artikel diatas menggunakan desain penelitian korelasional. Dari beberapa artikel yang direview sebagian sudah terindeks sinta S1-S6 atau scimago Q1-Q4. Hasil: Penulis menemukan 23 artikel dengan 20 artikel terbitan jurnal nasional dan 3 jurnal internasional. Hasil review yang dilakukan terhadap beberapa artikel diatas bahwa menunjukkan terhadap hubungan yang signifikan antara aktivitas fisik, pola makan dengan obesitas. Kesimpulan: Setelah melakukan proses review artikel penulis menemukan adanya hubungan antara aktivitas fisik dan pola makan terhadap obesitas anak usia sekolah dasar. Penulis juga menemukan bahwa banyak penyebab lain yang menjadi pengaruh obesitas anak diantaranya faktor genetik, faktor lingkungan dan media.
\end{abstract}

Kata kunci: aktivitas fisik; pola makan; obesitas

\section{Pendahuluan}

Kehidupan manusia tidak lepas dari sebuah makanan untuk bertahan hidup. Namun, kini menjadi masalah besar dibelahan dunia tentang kondisi obesitas dan status gizi seseorang. Dibuktikan Pada tahun 1980 angka obesitas di dunia meningkat secara pesat hingga dua kali lipat. Ditahun 2014 kejadian kelebihan berat badan pada orang dewasa mencapai angka 1,9 miliar dan 600 juta orang dewasa lainnya dinyatakan menderita obesitas. Tidak hanya itu, obesitas juga terjadi pada 41 juta anak yang berusia Balita atau dibawah 5 tahun (WHO, 2016). 
Menurut data dari World Health Organisation (WHO) angka terbesar obesitas ditemukan di wilayah Amerika dan terendah di wilayah Asia Tenggara. Obesitas menjadi masalah penting yang global salah satunya di negara Indonesia. Berdasarkan data (WHO, 2016) 28\% orang dewasa di indonesia menderita obesitas, sedangkan anak usia 5-2 tahun sebanyak 10,8\% terdeteksi mengalami obesitas.

20\%-30\% adalah angkta rata rata yang menjadi acuan ketika orang mengalami obesitas. Angka rata rata ini dapat dilihat dari BMI seseorang (Efendi, 2011). Menurut (Khomsan, 2010) Salah satu penyebab dari penyakit hipertensi, diabetes melitus, jantung koroner dan penyakit pernafasan adalah Ketika seseorang menderita obesitas. Bahkan dalam bukunya dituliskan bahwa obesitas memiliki dampak negatif bagi perhitungan panjang umur seseorang. Dari perolehan data WHO menyatakan bahwa peringkat ke 3 penyebab timbulnya penyakit kronis yaitu obesitas setelah konflik dan rokok. Dilihat dari penyebab obesitas yaitu acuan atau cara makan yang tidak sehat dengan mengkonsumsi kalori yang berlebihan dan kurangnya aktivitas pembakaran kalori yang dilakukan maka ada dua hal yang dapat membantu mengatasi masalah obesitas yaitu dengan merubah acuan atau cara makan ke makanan yang lebih sehat dengan mempertimbangkan nilai kesehatan yang tepat dan banyaknya kalori yang masuk kedalam tubuh atau melakukan aktivitas fisik yang cukup dengan asupan kalori yang masuk dan melakukan olahraga (Susilowati and Kuspriyanto, 2016).

Berdasarkan fakta yang ada penulis perlu memaparkan hasil penelitian artikel yang akan menjadi acuan penulis dalam menyusun artikel review ini. Berikut hasil penelitian dari (Ariani \& Af, 2017) dari penelitian tersebut diperoleh hasil bahwa banyak siswa yang memiliki cara makan yang normal tetapi melakukan aktivitas atau olahraga yang dengan porsi tinggi. Hasil dari uji antara asupan gizi dengan IMT dengan hasil akhir yaitu tidak ada keterkaitan. Selain itu aktivitas fisik dengan IMT memiliki pengaruh yang kuat. Penelitian yang dilakukan oleh (Danari, dkk 2013) menunjukkan angka 85,3\% anak mengalami obesitas dan 14,7\% anak tidak mengalami obesitas dengan sama sama memiliki aktivitas fisik yang ringan. Untuk menanggulangi hal ini diharuskan kepada anak anak untuk memperbanyak aktivitas dan dilakukan setiap hari dengan durasi 60 menit. Kesimpulan dari penelitian diatas bahwa aktivitas fisik memiliki keterkaitan yang signifikan dengan obesitas.

Artikel yang memaparkan tentang pola makan oleh (Ekawati \& Firnaliza, 2017) menyatakan ternyata penyakit obesitas memiliki sangkut paut dengan seseorang mengkonsumsi junk food. Kategori sering dalam mengkonsumsi junk food terdapat $(75,7 \%)$, selain itu hasil penelitian juga menunjukkan bahwa sampel penderita obesitas dan tidak obesitas memiliki perbedaan jumlah dalam mengkonsumsi junk food. Sehingga dapat disimpulkan bahwa gorengan adalah makanan yang banyak diminati oleh anak anak penderita obesitas. Selain itu penelitian dari (Nisak \& Mahmudiono, 2017) dengan hasil penelitian menyatakan bahwa penyebab kelebihan berat badan atau obesitas seseorang apat disebabkan dari mengkonsumsi makanan yaitu berupa jajanan.

Aktivitas fisik adalah gerak dari anggota badan yang dilakukan seseorang yang menggunakan energi dari dalam badan. Anjuran untuk aktivitas fisik yang dilakukan adalah sedikitnya 3 kali seminggu dengan waktu 60 sampai 90 menit. aktivitas dilakukan dengan porsi sedang dengan tujuan untuk menjaga kebugaran jasmani. Seperti yang dijelaskan (Nurcahyo, 2011) bahwa dari aktivitas pengeluaran energi yang dilakukan bisa menambah kebugaran jasmani, pengalaman gerak, mengenal jati diri, dan lingkungan. Manfaat lain yaitu dapat 
mencegah terjadinya obesitas atau kegemukan, peningkatan kesehatan dan pencegahan penyakit. Aktivitas fisik dapat meningkatkan kapasitas fungsional tubuh melalui peningkatan konsumsi oksigen (VO2 max), komposisi tubuh, kekuatan otot dan daya tahan. Selain dengan melakukan aktivitas fisik, obesitas juga dapat diatasi dengan mengatur pola makan.

Memperhatikan cara atau acuan makan dalam sehari hari ternyata penting dengan melihat banyaknya kasus obesitas yang terjadi. Ada berbagai dampak negatif yang disebabkan oleh rusaknya pola makan diantaranya kekurangan gizi, kelebihan berat badan, kekurangan berat badan, dan obesitas. Pola makan yang baik adalah mengatur komposisi dan jenis makanan yang tepat. Dengan pola makan dan pembakaran kalori yang tepat makan dapat mengurangi terjadinya kelebihan berat badan atau obesitas.

\section{Metode}

Ada beberapa tahapan yang dilakukan dalam metode penulisan artikel review ini. Yang pertama yaitu dengan menentukan tema yang dan penulis mengumpulkan artikel yang sesuai dengan kriteria inklusi melalui database google scholar. Penemuan jurnal penulis menggunakan metode PICO dalam menentukan kata kunci. Dalam pengumpulan artikel kata kunci yang digunakan adalah aktivitas fisik terhadap obesitas, pola makan terhadap obesitas, effect physical activity on obesity, and diet. Penulis mengumpulkan artikel yang akan direview dengan rentan tahun 10 tahun terakhir yaitu mulai dari tahun 2011 sampai dengan 2020. Data sekunder yang digunakan berupa article ilmiah yang berdasarkan penelitian korelasional aktivitas fisik dan pola makan terhadap obesitas.

Pengumpulan artikel nasional melalui Proses filtrasi kelayakan artikel untuk direview dilakukan melalui beberapa tahapan. Penulis menggunakan kata kunci tertentu sesuai dengan tema yang telah ditentukan. Telah ditemukan sebanyak 276 artikel dengan menggunakan database Google Scholar. Setelah diidentifikasi dengan dokumen duplikasi tersisa 73 artikel. Kemudian 19 artikel dikecualikan karena alasan tahun sehingga tersisa 54 artikel. Dari artikel yang tersisa 11 dikecualikan dengan alasan variabel hingga tersisa 36 artikel. Hingga akhirnya ditemukan 25 artikel yang dianggap layak berdasarkan kriteria inklusi data. Diseleksi lagi menurut jenis penelitian korelasional dan hasil tersisa 20 artikel. Selanjutnya proses filtrasi jurnal internasional melalui satu jenis database yaitu google scholar. Melalui database tersebut telah ditemukan sejumlah 8630 artikel. Kemudian setelah dikeluarkan dokumen duplikasi tersisa sebanyak 701 artikel. Dari dokumen duplikasi tersebut 236 dikecualikan karena alasan tahun sehingga tersisa 465 artikel. Dari jumlah tersebut 133 dikecualikan karena variabel sehingga tersisa 103 artikel. Hingga akhirnya ditemukan 5 artikel yang dianggap layak berdasarkan kriteria inklusi data. Diseleksi lagi menurut jenis penelitian korelasional dan hasil hingga tersisa 3 jurnal. 


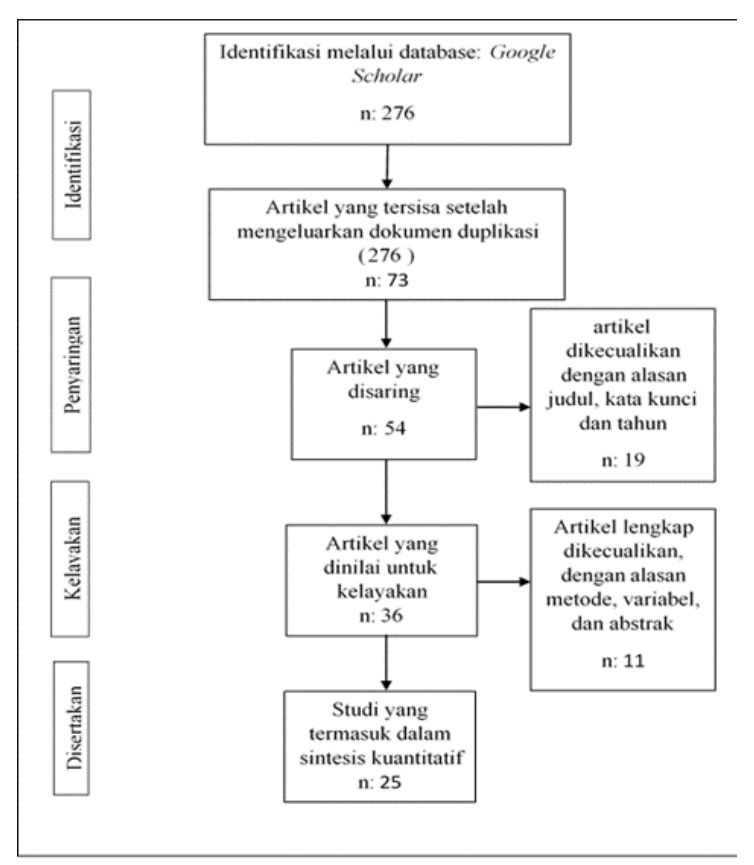

Gambar 1. Bagan Alur Filtrasi Jurnal Nasional

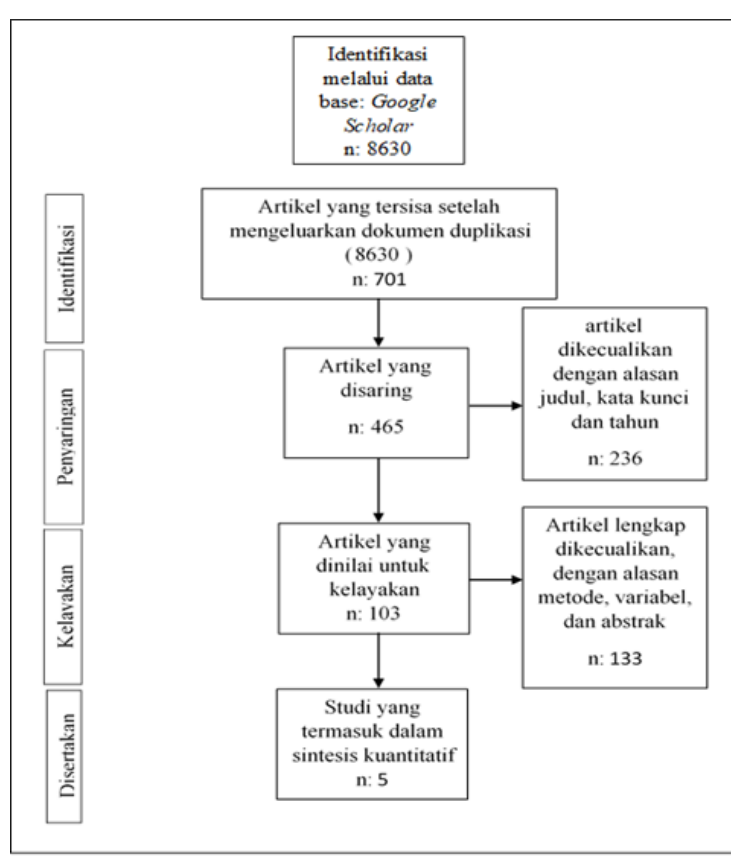

Gambar 2. Bagan Alur Filtrasi Jurnal Internasional.

\section{Hasil dan Pembahasan}

\subsection{Hasil}

Setelah melakukan pengumpulan dan seleksi kelayakan artikel yang sesuai dengan kriteria inklusi dari penulis, selanjutnya mereview artikel yang sudah terkumpulkan. Hasil analisis article review ini menghasilkan 23 penelitian dari 20 artikel nasional dan 3 artikel internasional. Dibawah ini adalah hasil paparan artikel yang telah direview oleh penulis.

Tabel 1. Hasil Analisis Article Review

\begin{tabular}{|c|c|c|c|c|c|}
\hline No & Penulis & $\begin{array}{l}\text { Desain } \\
\text { Penelitian }\end{array}$ & $\begin{array}{l}\text { Metode } \\
\text { Pengumpulan } \\
\text { Data }\end{array}$ & Responden & Hasil Penelitian \\
\hline 1 & $\begin{array}{l}\text { (Bidjuni et al., } \\
\text { 2014). }\end{array}$ & Korelasional & $\begin{array}{l}\text { Kuesioner, } \\
\text { Food } \\
\text { Frequency } \\
\text { Questionaire, } \\
\text { pita meter, } \\
\text { timbangan }\end{array}$ & 740 siswa & $\begin{array}{l}\text { Acuan atau cara } \\
\text { makan memiki } \\
\text { keterkaitan yang erat } \\
\text { dengan kejadian } \\
\text { obesitas }\end{array}$ \\
\hline 2 & $\begin{array}{l}\text { (Danari et al., } \\
\text { 2013). }\end{array}$ & Korelasional & $\begin{array}{l}\text { Kuesioner, } \\
\text { recall activity, } \\
\text { timbangan }\end{array}$ & 136 siswa & $\begin{array}{l}\text { Aktivitas fisik yang } \\
\text { dilakukan memiliki } \\
\text { keterkaitan dengan } \\
\text { obesitas pada anak }\end{array}$ \\
\hline 3 & $\begin{array}{l}\text { (Ekawati \& } \\
\text { Firnaliza, } \\
\text { 2017). }\end{array}$ & Korelasional & $\begin{array}{l}\text { Kuesioner, } \\
\text { pola makan, } \\
\text { sleep diary }\end{array}$ & 70 siswa & $\begin{array}{l}\text { Mengkonsumsi junk } \\
\text { food dan kejadian } \\
\text { obesitas memiliki } \\
\text { hubungan yang } \\
\text { berkaitan, selain itu } \\
\text { juga memiliki } \\
\text { keterkaitan antara }\end{array}$ \\
\hline
\end{tabular}




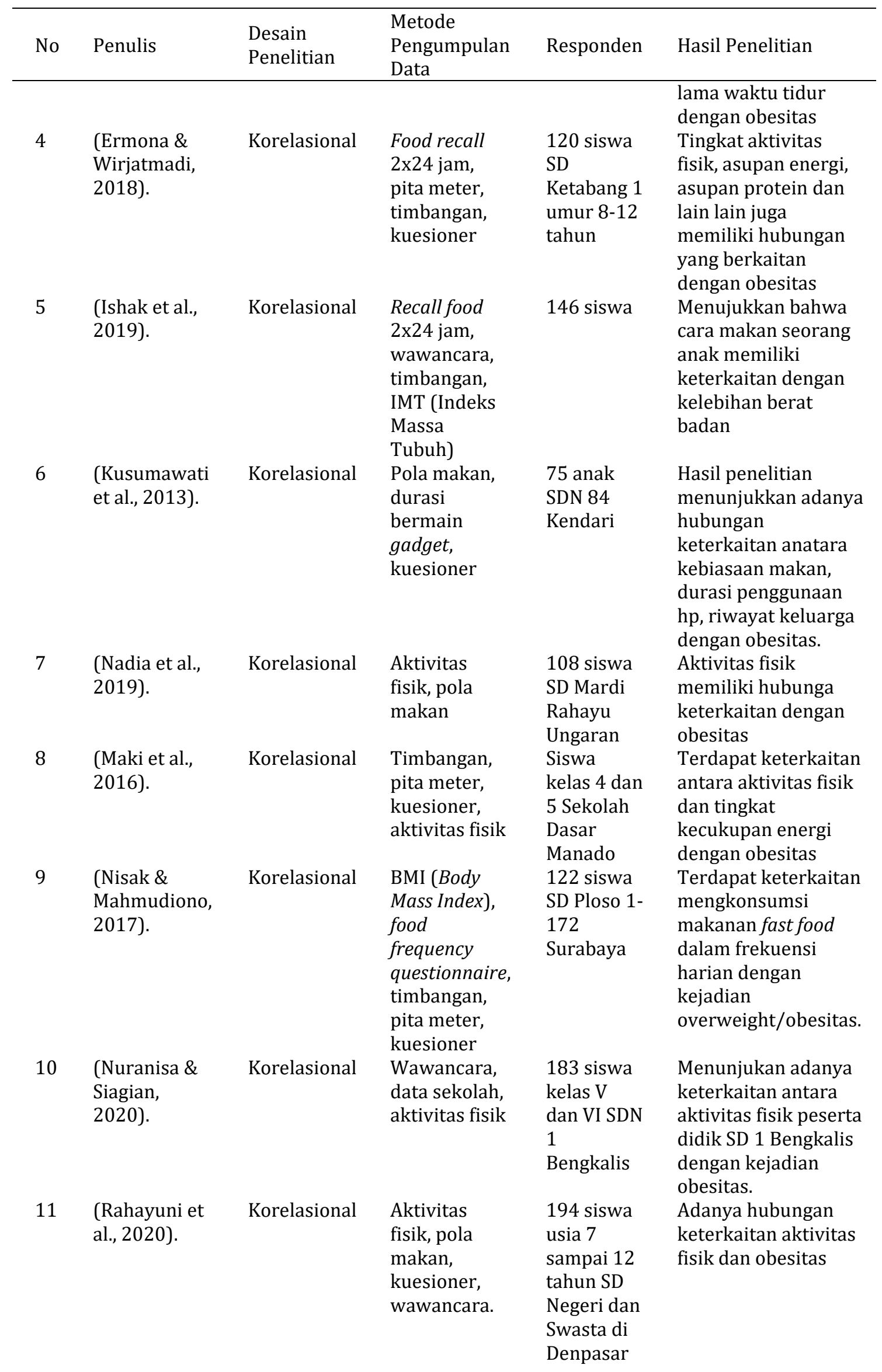


Sport Science and Health, 4(2), 2022, 184-193

\begin{tabular}{|c|c|c|c|c|c|}
\hline No & Penulis & $\begin{array}{l}\text { Desain } \\
\text { Penelitian }\end{array}$ & $\begin{array}{l}\text { Metode } \\
\text { Pengumpulan } \\
\text { Data }\end{array}$ & Responden & Hasil Penelitian \\
\hline 12 & $\begin{array}{l}\text { (Septiani \& } \\
\text { Raharjo, } \\
\text { 2017). }\end{array}$ & Korelasional & $\begin{array}{l}\text { Timbangan, } \\
\text { pita meter, } \\
\text { kuesioner, } \\
\text { data primer }\end{array}$ & 284 siswa & $\begin{array}{l}\text { Hasil penelitian } \\
\text { menunjukkan } \\
\text { terdapat hubungan } \\
\text { antara konsumsi fast } \\
\text { food, aktivitas fisik } \\
\text { dan faktor keturunan } \\
\text { dengan obesitas }\end{array}$ \\
\hline 13 & $\begin{array}{l}\text { (Setyani, } \\
\text { 2020). }\end{array}$ & Korelasional & $\begin{array}{l}\text { IMT (Indeks } \\
\text { Massa } \\
\text { Tubuh), } \\
\text { kuesioner, } \\
\text { aktivitas fisik, }\end{array}$ & $\begin{array}{l}308 \text { siswa } \\
\text { sd citra } \\
\text { berkat dan } \\
\text { sdn made } \\
1 \text { surabaya }\end{array}$ & $\begin{array}{l}\text { Hasil menunjukkan } \\
\text { ada keterkaitan } \\
\text { bermakna dari } \\
\text { aktivitas fisik dan } \\
\text { IMT, sehingga } \\
\text { kejadian obesitas } \\
\text { anak didapatkan } \\
\text { pada komunitas } \\
\text { dengan aktivitas fisik } \\
\text { yang rendah. }\end{array}$ \\
\hline 14 & $\begin{array}{l}\text { (Setyawan, } \\
2005 \text { ). }\end{array}$ & Korelasional & $\begin{array}{l}\text { Pola makan, } \\
\text { aktivitas fisik, } \\
\text { kuesioner, } \\
\text { timbangan, } \\
\text { pita meter }\end{array}$ & $\begin{array}{l}\text { Siswa dan } \\
\text { siswi SDN } \\
\text { Kauman } 1 \\
\text { Malang }\end{array}$ & $\begin{array}{l}\text { Hasil penelitian } \\
\text { bahwa antara acuan } \\
\text { atau cara makan } \\
\text { dengan aktivitas fisik } \\
\text { memiliki keterkaitan } \\
\text { dengan kejadian } \\
\text { obesitas }\end{array}$ \\
\hline 15 & $\begin{array}{l}\text { (Widyantari } \\
\text { et al., 2018). }\end{array}$ & Korelasional & $\begin{array}{l}\text { Kuesioner, } \\
\text { pola makan, } \\
\text { aktivitas fisik. }\end{array}$ & $\begin{array}{l}40 \text { siswa } \\
\text { sekolah } \\
\text { dasar di } \\
\text { badung } \\
\text { bali }\end{array}$ & $\begin{array}{l}\text { Terdapat hubungan } \\
\text { keterkaitan antara } \\
\text { pendapatan keluarga, } \\
\text { aktivitas fisik dan } \\
\text { pola makan dengan } \\
\text { kejadian obesitas }\end{array}$ \\
\hline 16 & $\begin{array}{l}\text { (Widyasari \& } \\
\text { Putri, 2018). }\end{array}$ & Korelasional & $\begin{array}{l}\text { Food recall } \\
2 \times 24, \text { pola } \\
\text { makan, } \\
\text { aktivitas fisik, } \\
\text { pola tidur, } \\
\text { wawancara }\end{array}$ & $\begin{array}{l}65 \text { siswa } \\
\text { kelas } 4 \text { dan } \\
5 \text { di } \\
\text { Sekolah } \\
\text { Dasar } \\
\text { Negeri } \\
\text { Banda } \\
\text { Aceh }\end{array}$ & $\begin{array}{l}\text { Asupan serat, } \\
\text { aktivitas fisik, pola } \\
\text { konsumsi fast food } \\
\text { dan lama waktu tidur } \\
\text { memiliki keterkaitan } \\
\text { dengan kejadian } \\
\text { obesitas }\end{array}$ \\
\hline 17 & $\begin{array}{l}\text { (Wilda \& } \\
\text { Desmariyenti, } \\
\text { 2020). }\end{array}$ & Korelasional & $\begin{array}{l}\text { Pita meter, } \\
\text { timbangan, } \\
\text { pola makan, } \\
\text { kuesioner. }\end{array}$ & $\begin{array}{l}826 \text { siswa } \\
\text { SD Negeri } \\
42 \\
\text { Pekanbaru }\end{array}$ & $\begin{array}{l}\text { Ada keterkaitan } \\
\text { natara pola makan } \\
\text { dengan kejadian } \\
\text { obesitas }\end{array}$ \\
\hline 18 & $\begin{array}{l}\text { (Paramitha, } \\
\text { 2013). }\end{array}$ & Korelasional & $\begin{array}{l}\text { IMT (Indeks } \\
\text { Massa } \\
\text { Tubuh), } \\
\text { kuesioner, } \\
\text { aktivitas fisik }\end{array}$ & $\begin{array}{l}120 \text { siswa } \\
\text { SD } \\
\text { Kecamatan } \\
\text { Pontianak } \\
\text { Selatan }\end{array}$ & $\begin{array}{l}\text { Hasil penelitian } \\
\text { menunjukkan bahwa } \\
\text { terdapat hubungan } \\
\text { keterkaitan antara } \\
\text { aktivitas fisik dan } \\
\text { acuan makan dengan } \\
\text { obesitas, selain itu } \\
\text { status ekonomi } \\
\text { orang tua juga } \\
\text { memiliki hubungan } \\
\text { dengan obesitas }\end{array}$ \\
\hline
\end{tabular}




\begin{tabular}{|c|c|c|c|c|c|}
\hline No & Penulis & $\begin{array}{l}\text { Desain } \\
\text { Penelitian }\end{array}$ & $\begin{array}{l}\text { Metode } \\
\text { Pengumpulan } \\
\text { Data }\end{array}$ & Responden & Hasil Penelitian \\
\hline 19 & $\begin{array}{l}\text { (Ali Suandana } \\
\text { \& Sidiartha, } \\
\text { 2014). }\end{array}$ & Korelasional & $\begin{array}{l}\text { IMT (Indeks } \\
\text { Massa } \\
\text { Tubuh), } \\
\text { aktivitas fisik }\end{array}$ & $\begin{array}{l}32 \text { siswa di } \\
\text { SD Negeri } \\
\text { 8 Dauhpuri } \\
\text { denpasar }\end{array}$ & $\begin{array}{l}\text { Bahwa waktu tidur } \\
\text { memiliki hubungan } \\
\text { dengan kejadian } \\
\text { obesitas }\end{array}$ \\
\hline 20 & $\begin{array}{l}\text { (Ariani \& Af, } \\
\text { 2017). }\end{array}$ & Korelasional & $\begin{array}{l}\text { food recall } \\
2 \times 24 \text { jam, } \\
\text { IMT (Indeks } \\
\text { Massa } \\
\text { Tubuh), } \\
\text { aktivitas fisik }\end{array}$ & $\begin{array}{l}76 \text { siswa } \\
\text { kelas 4-6 }\end{array}$ & $\begin{array}{l}\text { Hasil menunjukan } \\
\text { asupan gizi tidak } \\
\text { memiliki keterkaitan } \\
\text { dengan asupan gizi, } \\
\text { ttetapi aktivitas fisik } \\
\text { memiliki hubungan } \\
\text { keterkaitan dengan } \\
\text { IMT }\end{array}$ \\
\hline 21 & $\begin{array}{l}\text { (Hong et al., } \\
\text { 2016). }\end{array}$ & Korelasional & $\begin{array}{l}\text { Body Mass } \\
\text { Index (BMI), } \\
\text { physical } \\
\text { behavior }\end{array}$ & $\begin{array}{l}1.640 \text { anak } \\
\text { usia 3-15 } \\
\text { tahun }\end{array}$ & $\begin{array}{l}\text { Aktivitas fisik } \\
\text { memiliki hubungan } \\
\text { negatif dengan risiko } \\
\text { obesitas, ini berarti } \\
\text { kedua variabel } \\
\text { tersebut berkaitan }\end{array}$ \\
\hline 22 & $\begin{array}{l}\text { (Dine et al., } \\
\text { 2019). }\end{array}$ & Korelasional & $\begin{array}{l}\text { Body } \\
\text { composition } \\
\text { measurement, } \\
\text { Percentile } \\
\text { evaluation, } \\
\text { vertical jump, } \\
30 \text { meters } \\
\text { sprint }\end{array}$ & $\begin{array}{l}1966 \\
\text { Peserta } \\
\text { didik usia } \\
7 \text { hingga } \\
11 \text { tahun }\end{array}$ & $\begin{array}{l}\text { Terdapat korelasi } \\
\text { negatif antara } \\
\text { aktivitas fisik dan } \\
\text { obesitas. ini berarti } \\
\text { kedua variabel } \\
\text { tersebut saling } \\
\text { berkaitan. }\end{array}$ \\
\hline 23 & $\begin{array}{l}\text { (Dinaveric et } \\
\text { al., 2011). }\end{array}$ & Korelasional & $\begin{array}{l}\text { Nutrition, } \\
\text { physical } \\
\text { activity, } \\
\text { measured } \\
\text { height and } \\
\text { weight, BMI } \\
\text { (Body Mass } \\
\text { Indeks) }\end{array}$ & $\begin{array}{l}\text { Siswa } \\
\text { kelas 1-8 }\end{array}$ & $\begin{array}{l}\text { Pola makan dan } \\
\text { aktivitas fisik } \\
\text { memiliki keterkaitan } \\
\text { dengan kelebihan } \\
\text { berat badan. }\end{array}$ \\
\hline
\end{tabular}

Banyak faktor yang mempengaruhi terjadinya obesitas pada anak usia sekolah dasar baik secara langsung maupun tidak langsung. Faktor lingkungan menjadi penyebab utama terjadinya masalah obesitas. Pengaruh dari faktor lingkungan adalah dengan ketidakseimbangan antara pola makan, perilaku makan dan aktivitas fisik. Menurut (Susilowati and Kuspriyanto, 2016) pola makan adalah pemicu terjadinya masalah kegemukan hingga obesitas dengan mengkonsumsi makanan porsi besar, makanan tinggi energi, tinggi lemak tinggi karbohidrat dan rendah serat. Dengan kebiasaan makan yang melebihi dari kebutuhan harian maka terjadi penumpukan makanan yang tidak diubah menjadi energi akan mengendap dalam tubuh sehingga menjadi lemak. Aktivitas fisik disebut sebut sebagai faktor yang mempengaruhi kejadian obesitas pada anak didik sekolah dasar. Kurangnya aktivitas fisik kemungkinan merupakan salah satu faktor penyebab meningkatnya angka kejadian obesitas. Hal ini dibenarkan dengan melihat beberapa penelitian yang menyatakan bahwa aktivitas fisik memiliki pengaruh yang besar terhadap kejadian obesitas anak didik sekolah dasar. Penelitian yang dilakukan oleh (Nuranisa \& Siagian, 2020) hasil penelitian menunjukkan bawah adanya hubungan antara aktivitas fisik pesereta didik dengan kejadian obesitas. Pola makan adalah 
proses cara pemilihan jenis makanan, frekuensi makan, dan jumlah makanan yang akan dikonsumsi. Pola makan memiliki pengaruh yang besar terhadap kejadian obesitas pada anak. Seperti yang dijelaskan oleh (Sudargo, dkk 2014) pola makan adalah penyebab utama terjadinya obesitas dengan mengkonsumsi makanan dengan porsi besar yang melebihi dari kebutuhan harian, makanan tinggi energi, tinggi karbohidrat sederhana, dan rendah serat. Obesitas pada anak dapat dicegah dengan cara makan yang diimbangi dengan aktivitas fisik, diet yang benar, dan mengontrol makanan junkfood, (Fikawati, dkk 2017).

\subsection{Pembahasan}

\subsubsection{Faktor faktor yang mempengaruhi obesitas pada anak usia sekolah dasar}

Hasil review yang dilakukan terkait dengan obesitas ternyata banyak faktor yang mempengaruhi. Hal yang mempengaruhi obesitas pada anak tidak hanya dari dalam diri namun bisa datang dari luar. Faktor yang paling dekat dengan manusia yaitu faktor lingkungan yaitu rusaknya perilaku makan, pola makan dan aktivitas fisik. Dengan ketiga hal tersebut dilakukan secara tidak seimbang dengan jangka lama maka menyebabkan kelebihan berat badan. Pola makan adalah pemicu terjadinya masalah kegemukan hingga obesitas dengan pola konsumsi makan dengan porsi besar, makan makanan yang tidak sehat seperti makanan cepat saji dengan lemak jenuh tinggi. Dengan kebiasaan maka yang melebihi dari kebutuhan harian maka terjadi penumpukan makanan yang tidak digunakan menjadi energi akan mengendap didalam tubuh sehingga menjadi lemak. Obesitas pada anak dapat dicegah dengan cara makan yang diimbangi dengan aktivitas fisik, diet yang benar, dan mengontrol makanan junkfood. Selain mengubah pola makan obesitas juga dapat diatasi dengan aktivitas fisik. Manfaat olahraga dan aktivitas fisik adalah dapat menurunkan dan mempertahankan berat badan, selain itu dapat menurunkan tekanan darah, menaikkan kolestrol, dan mampu menurunkan risiko obesitas. Faktor penyebab obesitas yang utama adalah ketidak seimbangan antara asupan energi dan pengeluaran energi. Selain itu penyebab obesitas lain adalah keturunan, genetik, lingkungan.

\subsubsection{Hubungan aktivitas fisik dan pola makan dengan obesitas}

Berdasarkan dari analisis artikel yang telah dilakukan banyak ditemukan perbedaan juga persamaan antar artikel. Persamaan dalam artikel review ini yaitu beracuan pada penelitian korelasional dengan tujuan mengetahui hubungan keterkaitan yang signifikan antar variabel. Selain itu persamaan lain yaitu seluruh artikel yang direview menggunakan subjek siswa sekolah dasar. Perbedaan dapat dilihat dari variabel yang menunjukkan faktor yang mempengaruhi obesitas itu sendiri. Dengan variabel penelitian yang bervariasi, hasil penelitian menujukkan bahwa terdapat keterkaitan antara aktivitas fisik dan obesitas. Peneltiian lain juga menunjukkan hasil bahwa terdapat keterkaitan antara pola makan dan obesitas. Bahkan dari keseluruhan artikel yang direview penulis juga menunjukkan terhadap hubungan keterkaitan antara aktivitas fisik dan pola makan terhadap obesitas. Dari penelitian yang dilakkan penulis menemukan bahwa aktivitas fisik memiliki pengaruh tinggi terhadap kejadian obesitas. Pengertian aktivitas fisik itu sendiri yaitu gerak yang dilakukan oleh otot tubuh yang dalam setiap gerakannya membutuhkan pengeluaran energi. Jadi jika seseorang memiliki aktivitas fisik yang rendah maka pengeluaran energi dalam tubuh tidak maksimal. Sehingga dapat menyebabkan terjadinya penumpukan lemak akibat energi sisa makanan. Dengan begitu bisa dikatakan aktivitas fisik yang rendah dapat memicu terjadinya obesitas 
pada seseorang. Selain aktivitas fisik, pola makan menjadi penyebab utama terjadinya masalah obesitas. Pola makan yang tidak terkontrol dengan porsi makan yang berlebih maka menyebabkan terjadinya penumpukan lemak dalam tubuh. Selain porsi makan yaitu dalam pemilihan jenis makan. Jenis makanan cepat saji yang memiliki kalori tinggi yang dikonsumsi terus menerus dalam jangka panjang juga dapat menyebabkan terjadinya obesitas. Diera sekarang ini banyak pola makan yang rusak dikarenakan banyaknya makanan cepat saji yang diperjual belikan dengan tidak perlu menunggu lama dan tidak repot. Itu menjadi jalan pintas bagi seseorang yang tidak banyak waktu untuk memasak makanan sendiri.

\section{Simpulan}

Berdasarkan pembahasan yang telah dilakukan ternyata banyak penyebab yang mempengaruhi terjadinya obesitas anak usia sekolah dasar. Tidak hanya dalam diri namun juga faktor dari luar. Aktivitas fisik dan pola makan menjadi faktor utama dalam kejadian ini. Namun banyak juga faktor lain sebagai penyebab dari obesitas sendiri yaitu faktor genetik, faktor lingkungan dan faktor keturunan yang bisa dikataan faktor dari luar. Dari keseluruhan artikel yang telah direview menunjukkan hasil bahwa kurangnya aktivitas fisik dan cara makan yang tidak seimbang menjadi faktor terbesar dalam obesitas. Berdasarkan dari pembahasan yang telah dilakukan bahwa aktivitas fisik dan pola makan memiliki hubungan dengan obesitas. Kedua variabel tersebut memiliki andil yang besar dalam obesitas dan memiliki hubungan dalam mengontrol berat badan. Dalam mengatasi obesitas tidak hanya mengandalkan satu faktor saja namun faktor lain juga harus dipertimbangkan. Dengan melakukan aktivitas fisik yang berintensitas agak tinggi dan mengatur pola makan bisa meminimalisir terjadinya kelebihan berat badan atau obesitas.

\section{Daftar Rujukan}

Suandana, I. N. A., \& Sidiartha, G. (2013). Hubungan Aktivitas Fisik dengan Obesitas pada Anak Sekolah Dasar. Jurnal Kedokteran, 3(12), 1-13.

Ariani, N. L., \& AF, S. M. (2017). Keterkaitan Aktivitas Fisik Dengan Indeks Massa Tubuh (Imt) Siswa Sd Kota Malang. Care: Jurnal Ilmiah Ilmu Kesehatan, 5(3), 457-465.

Bambuena, M. I., Bidjuni, H., \& Rompas, S. (2014). Hubungan pola makan dengan kejadian obesitas pada anak usia 8-10 tahun di SD Katolik 03 Frater Don Bosco Manado. Jurnal Keperawatan, 2(2).

Danari, A., Mayulu, N., \& Onibala, F. (2013). Hubungan Aktivitas Fisik Dengan Kejadian Obesitas Pada Anak Sd Di Kota Manado. Jurnal Keperawatan UNSRAT, 1(1), 105729.

Dinarević, S., Branković, S., \& Hasanbegović, S. (2011). Relation of diet and physical activity to obesity in children in elementary schools. Journal of health sciences, 1(1), 44-49.

Dine, N., Ozbey, S., Besikci, T., Seyhan, S., Kalkan, N., \& gulay gezer. (2019). Obesity Preval e nce and Physical Fitness in School-aged Children. 7(3), 659-663. https://doi.org/10.13189/ujer.2019.070303

Efendi, M. (2011). Pengantar Kesehatan dan Gizi Anak. Fakultas Ilmu Pendidikan Universitas Negeri Malang.

Ekawati, F., \& Firnaliza, R. (2017). Hubungan Frekuensi Mengkonsumsi Junkfood Dan Durasi Tidur Dengan Obesitas Pada Anak Sekolah Dasar Di Wilayah Kerja Puskesmas Aur Duri Kota Jambi Tahun 2017. 048.

Ermona, N. D. N., \& Wirjatmadi, B. (2018). Hubungan Aktivitas Fisik Dan Asupan Gizi Dengan Status Gizi Lebih Pada Anak Usia Sekolah Dasar Di Sdn Ketabang 1 Kota Surabaya Tahun 2017. Amerta Nutrition, 2(1), 97. https://doi.org/10.20473/amnt.v2i1.2018.97-105

Fikawati, S., Syafiq, A., \& Veratamal, A. (2017). Gizi Anak dan Remaja. Rajawali Pers.

Hong, I., Coker-Bolt, P., Anderson, K. R., Lee, D., \& Velozo, C. A. (2016). Relationship between physical activity and overweight and obesity in children: Findings from the 2012 National Health and Nutrition Examination Survey National Youth Fitness Survey. American Journal of Occupational Therapy, 70(5), 1-8. https://doi.org/10.5014/ajot.2016.021212 
Ishak, S., Hatta, H., \& Hadi, A. J. (2019). Hubungan Pola Makan, Keterpaparan Media Dan Keturunan terhadap Kelebihan Berat Badan Pada Siswa Sekolah Dasar. 9(0451), 76-84.

Khomsan, A. (2010). Pangan dan Gizi Untuk Keshatan. Rajawali Sport.

Kusumawati, E., Fathurrahman, T., \& Tizar, E. S. (2013). Hubungan antara Kebiasaan Makan Fast Food, Durasi Penggunaan Gadget dan Riwayat Keluarga dengan Obesitas pada Anak Usia Sekolah ( Studi di SDN 84 Kendari ). Jurnal Kedokteran \& Kesehatan Hubungan, 2010, 87-92.

Maki, A., Mayulu, N., \& Djarkasi, G. s. s. (2016). Hubungan Asupan Energi Makanan Dan Aktivitas Fisik Dengan Kejadian Obesitas Pada Anak Sekolah dasar Kota Manado.

Nadia, R. M., Wahyuni, S., \& Widiyawati, sigit ambar. (2019). Hubungan Aktivitas Fisik dengan Kejadian Obesitas Pada Anak Sekolah Dasar di SD Mardi Rahayu Ungaran Kabupaten Semarang. 1(1).

Nisak, A. J., \& Mahmudiono, T. (2017). Pola konsumsi makanan jajanan di sekolah dapat meningkatkan resiko overweight/obesitas pada anak. Jurnal Berkala Epidemiologi, 5(3), 298-382.

Nuranisa, N., \& Siagian, A. (2020). Hubungan Aktivitas Fisik Dengan Obesitas Pada Anak Sekolah dasar N 1 Bengkalis Tahun 2017. XIV (01), 75-80.

Nurcahyo, F. (2011). Kaitan Antara Obesitas Dan Aktivitas Fisik Oleh: Fathan Nurcahyo UnBi. Medikora, 7(1), 87-96.

Paramitha, A. I. (2013). Hubungan Pola Makan Anak, Aktivitas Fisik Anak, dan Status Ekonomi Orang Tua dengan Obesitas Anak di Sekolah Dasar Kecamatan Pontianak Selatan. Fakultas Kedokteran, Universitas Tanjugpura.

Hafid, W., \& Hanafi, S. (2019). Hubungan Aktivitas Fisik dan Konsumsi Fast Food dengan Kejadian Obesitas Pada Remaja. Kampurui Jurnal Kesehatan Masyarakat, 1(1), 6-10.

Septiani, R., \& Raharjo, bambang budi. (2017). Pola Konsumsi Fast Food, Aktivitas Fisik dan Faktor Keturunan Terhadap Kejadian Obesitas. 2(3), 262-269.

Setyani, A. N., Winarso, H., \& Prayitno, S. (2020). Hubungan Aktivitas Fisik dengan Indeks Massa Tubuh Pada Anak Sekolah Dasar Kelas 4-5 di SD Citra Berkat dan SDN Made 1 Surabaya. Prominentia Medical Journal, 1(1). 18-29.

Setiawan, F. E. B. (2005). Hubungan Pola Makan Dan Aktivitas Fisik Anak Dengan Obesitas Pada Anak Usia Sekolah Dasar Di SDN 1 Kauman Malang.

Sudargo, T., Freitag, H., Kusmayanti, N. A., \& Rosiyani, F. (2018). Pola makan dan obesitas. UGM press.

Susilowati, K. (2016). Gizi dalam daur kehidupan. PT Refika Aditama: Bandung.

WHO, (2016) Data WHO.pdf?

Widyantari, N. M. A., Nuryanto, I. K., \& Dewi, K. A. P. (2018). Hubungan Aktivitas Fisik, Pola Makan, Dan Pendapatan Keluarga Dengan Kejadian Obesitas Pada Anak Sekolah Dasar. Jurnal Riset Kesehatan Nasional, 2(2), 214. https://doi.org/10.37294/jrkn.v2i2.121

Widyasari, R., \& Putri, chalida aulia. (2018). Faktor-faktor yang Berhubungan dengan Kejadian Obesitas Pada di Sekolah Dasar Negeri 54 Banda Aceh. 4(1), 174-181.

Wilda, I., \& Desmariyenti, D. (2020). Hubungan Perilaku Pola Makan dengan Kejadian Anak Obesitas. Jurnal Endurance, 5(1), 58. https://doi.org/10.22216/jen.v5i1.4361 